\title{
Sustainable coastal reclamation for community welfare in Bangkalan Regency, Madura Island, East Java
}

\author{
I Gusti Ayu Gangga Santi Dewi*; Bambang Eko Turisno
}

Faculty of Law, Diponegoro University, Indonesia

*To whom correspondence should be addressed.Email: ganggasanti@ gmail.com

\begin{tabular}{|l|l|l|l|l|}
\hline DOI: & Received: & Revised: & Accepted: & Published: \\
10.22437/ppd.v8i4.10832 & 13.12 .2019 & 17.02 .2020 & 04.11 .2020 & 07.11 .2020 \\
\hline
\end{tabular}

\begin{abstract}
Rapid population growth and the market expansion in various sectors in Bangkalan Regency have contributed to a rise in land demand. Therefore, the creations of new areas through land/coastal reclamation projects are taken place in this region. Based on this phenomenon, this study aims to analyze the potential and benefits of reclamation in Bangkalan Regency. The study uses a socio-legal approach and is a field research with verstehen (hermeneutic) approach. Data were obtained from informants, especially residents who have benefited from reclaimed land, village apparatus, and related agencies. Data were analyzed using triangulation technique. The results of the study found that in Bangkalan Regency, tourism in reclaimed land involves coastal communities, including fishermen, to manage the area, and it can improve community welfare. Furthermore, reclaimed land is used to expand their current land for settlement and business, as well as for the development of natural resource conservation such as mangroves and fish ponds. Reclaimed land in Bangkalan Regency is used for tourist destinations and settlement areas for the communities with their business.
\end{abstract}

Keywords: Reclaimed land, Sustainable, Welfare

JEL Classification: $\mathrm{O} 13, \mathrm{O} 18$

\section{INTRODUCTION}

In the era of globalization, the demand for land is growing, both for residential and business purposes. The large demand for the land has prompted the government to try to meet the needs of the land. One alternative is to transform the coastal zone into a new land known as coastal reclamation.

In theory, reclamation means an attempt to form new land in order to meet the needs of the land by hoarding or filling the area with certain materials. Reclamation is also one of the measures in urban expansion (Ni'am, 2005). Furthermore, Law No. 27 of 2007 jo Law No. 1 of 2014 on Management of Coastal Zone and Small Islands stated that reclamation in the coastal zone may only be carried out if the social and economic benefit derived is larger than the social and economic cost. 
The purposes of reclamation are to provide new jobs/business areas, to engineer coastal zone for better use, to improve coastal environment quality, to provide public utilization area in the coastal zone, and to provide housing for all income brackets (Sidarta, 1998). Suhud (1998) argued that the aim of coastal reclamation is to cater more to economic development interests. The availability of new land would decrease the demand for land, potentially reestablish watercrafts, open up opportunities for high-value development, strengthen marine tourism, increase government revenue, and boost economic growth of coastal communities. Based on its purposes, Asiyah, et al., (2015) suggested that the coastal reclamation would have a positive impact, in particular on the increasing quality and economic value of the coastal zone, the reduction of unproductive coastal land, the prevention of erosion, the improvement of aquatic ecosystem conditions, and the labor absorption.

Nevertheless, reclamation also has detrimental consequences both physically and socio-economically. In the physical aspect, reclamation would lead to the rise of turbidity level, marine pollution, siltation, increased risk of floods and puddle in coastal zone, and destruction of marine habitat and their ecosystems. In social-economic context, reclamation would bring socio-economic changes to coastal communities. These changes include difficulties in public access to coast and reduced livelihoods (especially for fishermen) (Huda, 2013; Retnowati, 2011; Djainal, 2012).

The negative impacts of coastal reclamation may be prevented by various activities depending on the terms of the location permit, environmental permit, and reclamation project permit stipulated in applicable regulations. If a requirement for obtaining a permit is not implemented, the government might reject or even cancel the coastal reclamation project even if the reclamation work has been carried out. In his research, Ruslin (2017) discovered the negative impacts of reclamation on the Losari Beach, Makassar City. As it experienced marine pollution and suffered a decline in sea water quality, the reclaimed land on the coast of Makassar was not properly utilized.

A number of regions in Indonesia, including Bangkalan Regency, have been actively creating new areas through coastal reclamation. Reclamation project in Bangkalan Regency has been taking place for a long time. Therefore, it is necessary to study the potential and benefits of reclamation in Bangkalan Regency.

\section{METHODS}

\section{Research approach}

This research used a socio-legal approach (Rahardjo, 2009). Research reconstructed social reality, by prioritizing the interaction between researchers and the objects being studied by sources and informants, and by taking note of the context that influences input, research process and results, as well as the interpretations.

\section{Sources of data}

Data in this research were obtained from informants, in particular those who had benefited from reclamation, villages apparatus in the research location, officials of the National Land Authority, Culture and Tourism Office, and Marine Affairs and Fisheries Office in Bangkalan Regency. 


\section{Data collection methods}

This study is a field research using the verstehen (hermeneutic) approach. Primary data were collected through unstructured interview with open-ended questions with respondents that were eligible to provide data for this study. Furthermore, observations were conducted with the aim of obtaining data on physical aspects of research locations, such as patterns of reclaimed land usage, land ownership, and behavior of residents in coastal zone towards reclamation.

This study is complemented by library research on benefit theory with regard to the progressive law for public welfare and the positive law in the form of coastal reclamationrelated policies, laws, and regulations.

\section{Data processing and analysis}

Data were analyzed using triangulation technique. This technique was conducted by comparing the data and its sources to capture differences and similarities based on qualifications, conditions of the data source when providing data, and its conformity to the documents as the research data.

Methods triangulation was carried out by checking of the consistency of findings through data-collection methods of participant observation and in-depth interviews, especially data from the parties related to the coastal reclamation in Bangkalan Regency.

Field notes were used to provide descriptions and data reflections for performing an interactive analysis (Sutopo, 1990). Data is classified through the indexing, shorting, grouping, and filtering. The next step is to reconstruct and analyze the problem in an inductive and qualitative approach after obtaining the results deemed to be valid and reliable. From the observation of the specific problem, we draw general conclusions (Sudarto, 2002).

The data analysis techniques in this research follow the interactive analytical model covering three concurrent flows of activity: data reduction, data display, and conclusion drawing/verification. The conclusion in this context is not equivalent to generalization.

\section{RESULTS AND DISCUSSION}

\section{Potential of reclamation in Bangkalan Regency, Madura Island}

Bangkalan Regency is regency in Madura Island, East Java Province, Indonesia. The region is located at the westernmost tip of Madura Island and is adjacent to the Java Sea in the north. Since the inauguration of the Suramadu Bridge, Indonesia's longest bridge, Bangkalan Regency has been the main gateway of Madura Island.

In consideration of its strategic position with its extensive supporting activities, Bangkalan Regency is a coastal city that has many beaches potentially to be developed as tourist destinations. One of the efforts to boost coastal tourism is the reclamation activity in Bangkalan Regency.

Tourism activities in reclaimed land involve the surrounding communities, including fishermen, to manage the coastal zone. Reclaimed land for business and tourism will restore the economic activities. The results of this study showed that tourism development in coastal zone received a positive response from the government of Bangkalan Regency, both through the provision of various assistances and the provision of supporting facilities. 
The development in the reclaimed land for tourism in Bangkalan Regency needs to be supported by several factors, including:

\section{a. Economic factors}

The development of the reclaimed land for tourism requires costs for the construction of service facilities such as sports tourism, restaurants, etc. and for providing a distinctive visual aesthetics of the coastal zone. It also requires funds for management related to local government policies and community capacity in managing reclaimed land for tourism. Therefore, it needs support and financial assistance from local and provincial governments by involving village-owned enterprises (Badan Usaha Milik Desa/BUMDES).

\section{b. Social factors}

The development in the reclaimed land should be informed clearly in transparent manner, and completely covered, among others, management, financing, and Environmental Impact Assessment (Analisis Dampak Lingkungan/AMDAL). The goal is to enable the public to give aspirations as government input in determining its policies.

\section{c. Cultural factors}

Reclaimed land for tourism should be characterized by local culture with specific characteristics. The history of local customs is a culture that provides a special identity to the region and brings out certain attractions with particular features.

\section{d. Environmental factors}

The development in the reclaimed land should strive to protect the environment by preventing negative impacts on the environment and to utilize less productive land. The key is to create an integrated and sustainable monitoring system of the reclaimed land based on natural resources and human resources in the surrounding area.

\section{Benefits of reclaimed land in Bangkalan Regency, Madura Island}

The management and utilization of reclaimed land are permitted by law as long as it takes into account the supporting capacity, sustainable development, ecosystem linkage, biodiversity, and environmental conservation. It is stipulated in Article 15 of Government Regulation No. 16 of 2004 on Land Use Management, which stated: "The use and utilization of land on islets and plots of land bordering on coasts, lakes, dams, and/or rivers shall observe public interests, supporting capacity, sustainable development, ecosystem linkage, biodiversity, and environmental conservation."

Utilization of reclaimed land in Bangkalan Regency aims not only to settle residents with their business either as fishermen or traders, but also to preserve aquatic ecosystem. The authority of the community to exploit and use land in coastal zone is explained in the Basic Agrarian Law Annex II point 2: "the State can grant such land to an individual or corporate body under a certain right, e.g. hak milik (right of ownership), hak guna-usaha (right to cultivate), hak guna-bangunan (right of use of structures), or hak pakai (right of use) according to the allotment or the need or grant it to a certain Power Body [e.g. a Department, Jawatan (Service), or Daerah Swatantra (Autonomous Region).”

Based on the explanation in the Basic Agrarian Law, state-owned land could be granted to the people who need it. Application for land rights from reclamation are addressed to the government either by individuals or legal entities under the prevailing 
laws and regulations. The findings of the research related to the utilization of reclaimed land in Bangkalan Regency are given as follows.

- In Kamal district, Socah district, Labang district, Kwanyar district, and Modung district, the reclaimed land is used by individuals for settlement and by the private sectors (business entities) for their business. The community stated that they own the land of their parent's legacy, and sell or buy under private deed. Reclaimed land is used for tourism attractions run by local communities in cooperation with the local government, and also for expanding their land for specific purposes including stalls, fishponds, and stores. The community is enthusiastic if the reclaimed land is utilized to develop coastal tourism in their area because it could improve their quality of life.

- In Kwanyar district, Modung district, and Sreseh district, the reclaimed land is used to expand the business. In Kamal district, there was defunct sea port. After the reclamation, it serves as the place for ship unloading and repair. The positive impact to communities is that many people who were initially working as fishermen are now laborers in the ship repair and ship unloading places.

- In Socah district, Peti Kemas Port was built in an area of 100 ha with the acquisition of privately-owned lands. The reclaimed land for seaport area is used for unloading of imported goods and loading of export goods, settlements, fish ponds, and lighthouse. Despite the community's rejection in the beginning, they finally gave their land because it's beneficial for them. Reclamation in Socah district has given the local communities positive benefit in terms of social, economic, cultural, and legal aspects. It experienced an increase in the economic value of regional incomes in the form of import-export taxes and employment.

The findings of this research are in line with the results of the study conducted by Reflis (2017) in the coastal reclamation of Kawasan Ekonomi Khusus (KEK)/Special Economic Zone Tanjung Api-Api. The reclamation project, which added 200 hectares of land in Palembang, South Sumatra, had a positive impact for the central government, the government of South Sumatra, and the government of Banyuasin Regency. KEK Tanjung Api-Api is a strategic location because it is the economic gate of Sumatra, Java, Bangka Belitung, Kalimantan, and other ASEAN countries. Another similar study conducted by Suganda, et al. (2009) found that the sustainable development in the reclaimed land of KEK Tanjung Api-Api should meet three pillars, namely environmental, economic, and social aspects. They are carried out in a balanced and dynamic manner with local development and nonlinear, and include feedback processes.

Based on data from Marine Affairs and Fisheries Office in Bangkalan Regency (2019), most coastal zones in Bangkalan Regency have mangrove forests, with two types of management of mangrove ecosystem: (1) mangrove ecosystem as greenbelt for ponds; (2) mangrove ecosystem as rehabilitation zone of protected areas. Mangrove ecosystem on the southern coast of Bangkalan Regency is a natural mangrove forest and a protected forest. While the mangrove forest in Modung district is a natural forest, the forest in Kwanyar district is a forest rehabilitation area. Mangrove area in reclaimed area can be used as a tourist destination.

The mangrove ecosystem is an area that connects coastal ecosystem and terrestrial ecosystem. It only grows in sheltered coastal areas without waves, storms, and erosion. 
According to Alikodra (1999), mangrove forests have special characteristics: limited to particular locations, unique ecological role as opposed to the role of other ecosystems, high economic value of products, and renewable as a natural resource.

Reclaimed land for embankment as coastal belt is very beneficial to the sustainability of mangrove ecosystems. The management of mangrove forest conservation area in Bangkalan Regency is stipulated in 2009-2029 Spatial Plan of Bangkalan Regency. It is environmentally sound sustainable development with the aim of improving the social and economic condition of the community and providing the replanting for damaged mangrove forests. Mangrove forests are one of the most important parts of the entire regional development system (Alikodra, 1999).

Coastal residents can make high-value mangrove wood products and handicrafts (in the form of bags and shoes) from its leaves; thereby increasing their incomes. The reclaimed land in Bangkalan Regency is also intended for fish ponds and sea salt production. The reclamation activities for fish ponds in Bangkalan Regency are increasing every year, thus raising the income of surrounding communities. Export businesses by village-owned enterprises (BUMDES) are very helpful for coastal communities especially fishermen.

\section{CONCLUSIONS AND RECOMMENDATIONS}

\section{Conclusions}

Reclaimed land for tourism in Bangkalan Regency by involving coastal communities including fishermen may improve people's welfare. Reclaimed land for business and tourism can invigorate economic activities in the surrounding communities. These activities include making handicrafts as souvenirs by fishermen's wives, restaurants, and home industries from mangrove conservation.

Reclaimed land use is permitted by law as long as it takes into account the supporting capacity, sustainable development, ecosystem linkage, biodiversity, and environmental conservation. In addition to tourism and settlements for residents and their business, either as fishermen or traders, reclaimed land in Bangkalan Regency is useful for the sustainability and preservation of aquatic ecosystems including mangrove.

\section{Recommendations}

The development potential in the coastal zone could be followed up with similar research for other regions with reclamation projects. The research should be conducted in cooperation with government offices related to policy makers of coastal reclamation. It should be done with an in-depth study of the impacts of coastal reclamation by involving competent authorities concerned and a comprehensive interdisciplinary research.

The use of reclaimed land will support an increase in tourist visits, both for domestic and foreign tourists. Port in reclaimed land is expected to create a cooperation and partnership between the government, domestic and foreign investors, and the community, thereby increasing local revenue and state income in the form of foreign exchange in export and tourism sectors. 


\section{REFERENCES}

Alikodra, H.S. (1999, May 18). Implementasi Konservasi Hutan Mangrove di Indonesia. [paper presentation]. Working meeting Coastal and forest management in Indonesia, Direktorat Jenderal Bangda Depdagri. Jakarta.

Asiyah, S., Rindajorno, M.G., \& Muryani, C. (2015). Analisis Perubahan Pemukiman dan Karasteristik Pemukiman Kumuh Akibat Abrasi dan Inundasi di Pesisir Kecamatan Sayung Kabupaten Demak Tahun 2003-2013. GeoEco, 1(1), 83 -100.

Huda, M.C. (2013). Pengaturan Perizinan Reklamasi Pantai Terhadap Perlindungan Lingkungan Hidup. Perspektif, 18(2):126 - 135

Djainal, H. (2012). Reklamasi Pantai dan Pengaruhnya Terhadap Lingkungan Fisik di Wilayah Kepesisiran Kota Ternate. Jurnal Lingkungan Sultan Agung, 1(1), 1 - 13

Harsono, B. (2002). Hukum Agraria Indonesia. Jakarta: Djambatan

Indonesia. (1960). Undang-Undang Nomor 5 Tahun 1960 tentang Peraturan Dasar Pokok-Pokok Agraria. State Gazette of The Republic of Indonesia of 1960 Number 104. Jakarta: Sekretariat Negara

Indonesia. (2004). Peraturan Pemerintah Nomor 16 Tahun 2004 tentang Penatagunaan Tanah. Jakarta: Sekretariat Negara

Indonesia. (2007). Undang-Undang Nomor 27 Tahun 2007 tentang Pengelolaan Wilayah Pesisir dan Pulau-Pulau Kecil. State Gazette of The Republic of Indonesia of 2007 Number 84. Jakarta: Sekretariat Negara

Indonesia. (2014). Undang-Undang Nomor 1 Tahun 2014 tentang Perubahan Atas Undang-Undang Nomor 27 Tahun 2007 tentang Pengelolaan Wilayah Pesisir dan Pulau-Pulau Kecil. State Gazette of The Republic of Indonesia of 2014 Number 2. Jakarta: Sekretariat Negara

Karnawati, D. (2007). Mekanisme Gerakan Massa Batuan Akibat Gempabumi, Tinjauan dan Analisis Geologi Teknik, Jurnal Dinamika Teknik Sipil, 7(2), 179-190.

Ni’am. (2005). Menuju Harmonisasi Sistem hukum Sebagai Pilar Pengelolaan Wilayah Pesisir Indonesia, Jakarta: Coastal Resource Management Project, Mitra Pesisir

Rahardjo, S. (2009). Lapisan Lapisan Dalam Studi Hukum. Bandung: Alumni

Reflis, R. (2017). Reklamasi Dan Restorasi Ekologi Kawasan Tanjung Api-Api Provinsi Sumatera Selatan. Jurnal AGRISEP, 16(1), 57 - 70.

Retnowati, E. (2011). Nelayan Indonesia dalam Pusaran Kemiskinan Struktural. Perspektif, 16(3), 149 - 195

Santi, G.S. (2019). Penolakan Masyarakat Terhadap Reklamasi Telok Benoa Provinsi Bali. Diponegoro Private Law Review, 4(1), 390 - 400

Sidarta.(1998). Reklamasi? Tidak Reklamasi? [Paper presentation]. Coastal and forest management in Indonesia. PKSPLIPB-CRC-University of Rhode Island

Sudarto, S. (2002). Metode Penelitian Filsafat, Jakarta: Raja Grafindo

Suganda, E. Yatmo,Y.A. \& Atmodiwirjo, P. (2009). Pengelolaan Lingkungan dan kondisi Masyarakat Pada Wilayah Hilir Sungai. Jurnal Makara, Sosial Humaniora. 13(2) $143-153$.

Suhud, S. (1998). Penanggulangan Reklamasi Yang Telah Berjalan. Coastal and forest management in Indonesia. PKSPLIPB-CRC-University of Rhode Island

Sutopo, H.B. (1990). Metodologi Penelitian Kualitatif Bagian II. Surakarta: Universitas Negeri Sebelas Maret Press 
Ruslin, I.T. (2017). Subaltern dan Kebijakan Pembangunan Reklamasi Pantai di Kota Makasar. Jurnal Politik Profetik, 5( 2), 185 - 199

Yulianti, R., Ikhwan, M. \& Zaman, N. (2015). Urgensi Pengaturan Reklamasi Pantai Di Wilayah Pesisir Selatan Madura, Yustisia, 4(1), 103 - 121

(C) 2020 by the authors. Licensee JPPD, Indonesia. This article is an open-access article distributed under the terms and conditions of the Creative Commons Attribution (CC BY) license (http://creativecommons.org/licenses/by/4.0/). 